\title{
Adil Dünya İnancının Yakın Kişilerarası İlişkiler Açısından Ele Alınması
} Consideration of Belief in a Just World Regarding Close Relationships

\section{Ayşegül SAYAN KARAHAN[1]}

Bu alanyazın incelemesi, adil dünya inancı kavramının yakın kişilerarası ilișkiler açısından ele alınması hakkında bilgileri sunmaktadır. Adil dünya inancl; ruh sağlığl, adli psikoloji, endüstri-örgüt psikolojisi, sosyal psikoloji ve din psikolojisi gibi alanlarda çalışılmış olsa da yakın kişilerarası ilişkiler alanında sınırlı olarak ele alındığı ve bu alanda bir boșluk ve gereksinim olduğu görülmüştür. Bireylerin hak ettiklerini yaşadıklarına ve yaşadıklarını hak ettiklerine inanmaları anlamına gelen adil dünya inancı kavramının işlevleri, özellikleri ve gelișimi hakkında kuramsal açılamalar gözden geçirilmiş, genel ve kişisel adil dünya inancı ayrımı ile hemen gelen adalet ve önünde sonunda gelen adalet ayrımı ele alınmış, adil dünya inancını destekleyen kuramlar kısaca açıklanmıștır. Ulaşılabilen ve yakın kişiler arası ilişkilerle ilişkili olabilecek alanyazın özetlenmiștir. Adil dünya inancının bireylerin çift ve evlilik ilişkisi içinde yaşadıkları olumlu ve şiddet, istismar, ihmal, aldatma gibi olumsuz deneyimleri bilişsel ve davranışsal olarak nasıl ele alacaklarını etkileyebileceği görülmektedir. Adil dünya inancının yakın kişilerarası ilişkilerde hem olumlu hem de olumsuz etkileri olabileceği görülmektedir. Bireylerin çift ve evlilik ilişkisi içinde yaşadıkları bu tür deneyimlerde içine girecekleri döngüler ile affetme, ilişkide kalma ya da ayrılma süreçlerinde görülebilecek adil dünya inancının yansımaları vurgulanarak tartışılmıștır. Adil dünya inancının yakın kişiler arası ilişkilerde ele alınmasına ilişkin daha ileri nitel ve nicel araștırmalarla ilgili öneriler sunulmuştur.

Anahtar Kelimeler: adil dünya inancı, yakın kişilerarası ilişkiler, aile danışmanlığı

Received Date:25 July 2021

This review provides information on just world belief in terms of close relationships. Although just world belief has been studied regarding mental health, forensic, industrial-organizational, social and religion psychology, there have been limited studies regarding close relationships and there is a gap and need in this field. Theoretical explanations regarding functions, characteristics and development of just world belief, which means that individuals believe that they live what they deserve and deserve what they live, has been reviewed, the distinction between general-personal belief in a just world and immediate-ultimately justice has been discussed, supporting theories were briefly explained. The accessible related literature were summarized. Belief in a just world can affect how individuals handle cognitively and behaviorally positive and negative experiences such as violence, abuse, neglect, infidelity in a couple and marital relationship. Belief in a just world can have both positive and negative effects on close relationships. The cycles that individuals will enter in case of such experiences in a couple or marital relationship and the reflections of the belief in a just world that can be seen in the processes of forgiveness, staying in a relationship or separation were discussed. Suggestions for further qualitative and quantitative research were presented.

Keywords: belief in a just word, close relationsihps, family counseling 


\section{GíRiş}

dil dünya inancı; son on yıllar boyunca ruh sağlığı, adli psikoloji, endüstri-örgüt
psikolojisi, sosyal psikoloji ve din psikolojisi gibi çalışma alanlarında ilgi görmeye
başlayan bir kavram olarak gelişmektedir. Adil dünya inancı kavramının hem bireysel, hem ilişkisel, hem de sosyal düzeyde nitelik, süreç, etki ve sonuçları hakkında alanyazın gelişmektedir. Bu derleme çalışmasında öncelikle adil dünya inancı kavramı tanıtılmış, bu kavram ile ilişkili araştırmalar gözden geçirilmiş ve daha sonra adil dünya inancı yakın kişiler arası ilişkiler alanı açısından tartışılmıştır.

Adil dünya inancının çift, evlilik, aile ilişkileri çalışmaları kapsamında ele alındığı yurt dışı ve yurt içi sınırlı sayıda çalışmaya rastlanmış ve bu alanda bir boşluk olduğu görülmüştür. Adil dünya inancının yakın kişilerarası ilişkilerin ele alındığı çift, evlilik, aile ve boşanma süreci danışmanlığı alanları kapsamında da ele alınabilecek önemli bir kavram olabileceği düşünülmüştür. Çift, evlilik, aile ve boşanma süreci danışmanlığı alanları özel bir yakın kişilerarası ilişki türü olan evliliğin hazırlık, sürdürme ve sonlandırma aşamalarıyla ilgili iyileştirici ve geliştirici uygulamaları içermektedir. Çift, evlilik, aile ya da boşanma süreci danışmanlığı alan bireylerin sahip oldukları adil dünya inancına ilişkin özellikleri ile bu özelliklerin bireyler, bireylerin oluşturduğu çift ve evlilik ilişkileri, çift ve evlilik ilişkilerinde çözmeleri gereken kriz ve problem durumları, çift ve evlilik ilişkilerinde güçlü yönleri gibi açılardan nasıl ele alınabileceğine ilişkin bir bakış açısı geliştirilmeye çalışılmıştır.

Adil dünya inancı kavramının yakın kişilerarası ilişkiler alanında ele alınmasının, bu kavramın bireyler ve aralarındaki ilişki dinamikleri üzerindeki etkileri ve sonuçlarının çift, evlilik, aile ve boşanma süreci danışmanlığı uygulama ve çalışmalarında daha iyi anlaşılabilmesi açısından katkı sağlayabileceği düşünülmüştür. Böylelikle adil dünya inancının çift, evlilik, aile ve boşanma süreci danışmanlığı alanındaki çalışma ve uygulamalara yansımalarını fark etmenin bu alanlarda etkililiği artırmaya hizmet edebileceği düşünülmüştür. Buna ek olarak, adil dünya inancının kişilerarası ilişkiler alanında ele alındığı daha ileri araştırmalara olan gereksinimin vurgulanması amaçlanmıştır.

\section{Adil Dünya İnancı Kavramının Kuramsal Çerçevesi}

Lerner'in $(1965 ; 1977 ; 1980)$ adil dünya inancı kuramına göre, bireyler dünyanın adil bir yer olduğuna, herkesin hak ettiğini yaşadığına ve yaşadığını hak ettiğine inanmaktadırlar. Lerner aslında dünyanın adil bir yer olmamasına rağmen bireylerin dünyanın adil bir yer olduğuna inanma ihtiyacı, motivasyonu ve isteği nedeniyle inanmalarından dolayı adil dünya inancının bir yanılsama olduğunu ileri sürmektedir. Bu yanılsamanın işlevleri olduğu ileri sürülmüștür. 
Lerner'e göre adil dünya inancı varsayımı yani bireylerin davranışları ile istendik sonuçlara ulaşıp istenmedik sonuçlardan kaçınabileceklerine olan inançları, bireylerin fiziksel ve sosyal çevrelerini sabit ve kararlı olarak algılamalarını, geleceğe dönük planlar yapabilmelerini, geleceği yordayabilmelerini ve yaşadıkları çevreyi kontrol edebilmelerini sağlamaya, bir diğer ifadeyle bireylerin çevreye uyumuna katkı sağlamaktadır. Kontrol edilebilir ve yordanabilir bir çevre içinde yaşayan bireylerin uzun vadeli amaçlara yönelik davranışlarda bulunabilecekleri öngörülmektedir. Hafer'e (2000) göre, adil dünya inancl, harcanan gayretin ve yapılan yatırımın bireye olumlu yönde geri döneceği beklentisiyle bireylerin amaçları ve planları için motivasyon sağlamaktadır. Dünyanın adil bir yer olduğu inancı, bireylere hak ettikleri gibi davranılacağı ve haksız yere kurban konumunda olmayacakları konusunda bir güvence işlevi görmekte ve bu güven bireylerin içinde yaşadıkları dünyayı aktif olarak yapılandırabilmelerini sağlamaktadır. Adil dünya inancı, bireylerin gelecek algılarında güven duygusunun daha fazla yer almasına yol açmaktadır (Coşgun, 2010; Çakır ve Şen, 2012; Giray, 2009; Gökler Danışman ve Berberoğlu, 2016; Otto ve Dalbert, 2005; Öcel ve Aydın, 2010).

Adil dünya inancının; bireyin kendi kendine adil davranmasını sağlaması, diğerlerinin ona adil davranacağını düşünerek uzun süreli amaçlar edinebilmesi ve adaletsizliğe uğradığında bu durumu sindirebilmesi olmak üzere üç işlevinden söz edilebilmektedir (Correia, Kamble ve Dalbert, 2009; Demir, 2012). Adil dünya inancının eksikliği; bireyin şüpheli, tedirgin ve savunmasız hissetmesine, geleceği yordayamadığı durumlarda çevreye uyum problemleri yaşamasına neden olmaktadır. Yaptıkları olumlu davranışların ödüllendirildiği, olumsuz davranışların cezalandırıldığı, herkesin hak ettiği sonuca ulaştığı ve hiç kimsenin haksız yere mağdur durumunda olmadığı adil bir dünyada yaşadıklarına inanmadıklarında bireylerin çabaları anlamını yitirmektedir. Sonucu yordanamayan adaletsiz olaylar, bireyin içinde yaşadığı kaotik çevreye uyum problemlerine, güçsüzlük, çaresizlik ve acizlik gibi duygular yaşamasına yol açmaktadır (Coşgun, 2010; Giray, 2009; Öcel ve Aydın, 2010). Lipkus ve Siegler (1993) bireylerin davranışları ile karşılaştıkları sonuçların uygunluğuna inanma eğiliminde olduklarını ve bu uygunluğun aksine durumlarda geleceğin öngörülemez bir hal alacağını, dolayısıyla insanların bu yanılsamalarını ancak davranışlar ve sonuçlar arasındaki ilişkiye inanarak sürdürebildiklerini vurgulamaktadır.

Adil dünya inancı kuramının ileri sürülmesinde, bireylerin karşılaştıkları olaylardaki adaletsizlikleri akla uygun hale getirme yatkınlıklarının fark edilmesi etkili olmuştur. Dolayısıyla, adil dünya inancına ilişkin erken çalışmalar yaygın olarak adaletsizliği meşrulaştırma ve kurbanı suçlama eğilimi üzerine odaklanmaktadır (Kılınç ve Torun, 2011). Adil dünya inancının yansımaları çeşitli bilişsel stratejiler ile görülebilmektedir. 
Janoff-Bulman'ın (1989) ileri sürdüğü Temel Varsayımlar Modeli'ne göre bireyler; dünyanın iyiliği, dünyanın anlamlılığı ve kendilik değeri olmak üzere üç temel varsayıma sahiptirler. Dünyanın iyiliği varsayımı, bireyin dünyayı ne kadar olumlu gördüğünün derecesini ifade etmektedir. Dünyanın iyiliği varsayımının bir boyutu kişisel olmayan dünyanın iyiliği iken diğer boyutu insanların iyiliğidir. Kişisel olmayan dünyanın iyiliği inancının yüksek olmasının dünyayı daha olumlu görmekle ilişkisi bildirilmektedir. Adalet, kontrol edilebilirlik ve rastlantı ilkeleri doğrultusunda kimin olumlu, kimin olumsuz deneyimler yaşayacağına ilişkin düşüncelere dayanan dünyanın anlamlılığı varsayımı, bireylerin dünyayı anlamlı ve kabul edilebilir olarak algılamasına katkı sağlamaktadır.

Heider (1958) adil dünya inancının daha genel bir bilişsel denge ilkesinden kaynaklanan yaygın bir bilişsel yanlılık olduğunu ileri sürmüştür. Bireyler, iyilik ve mutluluğu, kötülük ve cezayı ilişkili olarak düşünmekte ve adaletin hüküm sürmesi için bu ikililerin birlikte bulunmasını beklemektedir. Öte yandan iyilik ile mutsuzluk, kötülük ile mutluluk birlikte bulunduğunda ise bu durum bireyde bilişsel çelişkiye yol açmakta, bu bilișsel çelişki bireyi rahatsız etmekte ve birey bu çelişkiyi gidermeye güdülenmektedir (Akgün,2019). Heider'in “Denge Kuramı”, Festinger'in “Bilişsel Çelişki Kuramı”, Rosenberg ve Abelson’un “Bilişsel Denge Kuramı", Newcomb'un "Objektif Denge Kuramı" bireylerin bu tür bir tutarsızlıkla karşılaştığında bu durumdan psikolojik uyum durumuna ulaşabilmek için çeşitli yollar deneyeceğini ve bunun bir gereksinim olduğunu ifade etmektedir (Kılınç ve Torun, 2011).

Dünyanın aslında sabit, düzgün ve hakkaniyetli olmadığını gösteren ağır travmatik yaşantılar ya da tekrarlayan adaletsiz deneyimlerin varlığında bireyler bu inançlarını değiştirmek zorunda kalabilmektedir (Kılınç ve Torun, 2011). Hafer (2000) bireylerin bu inançtan vazgeçmemek için direndiklerini belirtmektedir. Adaletsizliklere tanık olmak ya da hak etmeyen bireylerin kurban durumunda olması adil dünya inancını tehdit ettiğinde bireyler adil dünya inançlarını sürdürebilmek için adaletsizliği meşrulaştırmakta, yaşanan olumsuzluğu olduğundan küçük görmekte, başına gelen olumsuzluklara kurbanın kendisinin neden olduğuna inanma eğiliminde olmakta, hatta kurbanı suçlamaktadır (Furnham ve Proctor, 1992; Giray, 2009; Harper ve Manesse, 1992; Harper, Wagstaff, Newton ve Harrison 1990; Kleinke ve Meyer, 1990; Lerner ve Simon, 1966; Montada, 1998; Uğur ve Akgün, 2005).

Adil dünya inancını kişisel adil dünya inancı ve genel adil dünya inancı olarak iki kategoride ele almak mümkündür. Kişisel adil dünya inancı bireyin kendi yaşantısındaki deneyimlerini ne kadar adil gördüğüyle ilgili olarak ele alınmaktadır. Genel adil dünya inancı ise esasen dünyanın ne kadar adil bir yer olduğuna ilişkin bireyin algısı ile ilgili olarak ele alınmaktadır. (Dalbert ve Stoeber, 2006). Her ne kadar aralarında bir ilişki bulunsa da, genel ve 
kişisel adil dünya inancı farklı alanlara ilişkin adalet algılarını içermekte olduğundan ayırt edilmeleri gerekmektedir (Dalbert, 1999).

Bireylerin kişisel yaşantılarını genel anlamda dünyadan daha az tesadüfî, daha adil ve olumlu olarak gördükleri yani bireylerin kendi kişisel dünyalarını daha öngörülebilir ve güvenli olarak algıladıkları ileri sürülmektedir. Dalbert (1999; 2001) bireylerin daha bağlı oldukları kişisel adil dünya inancının bireylerin adalete ilişkin tutumlarını ve inançlarını daha çok yansıttığını vurgulamaktadır. Calhoun ve Cann (1994) bireylerin genel adaletsizliklere daha tarafsız bakabiliyorken, kendi yaşamlarında uyum ve tutarlılı̆̆ daha çok önemsediklerini ve kendilerine ilişkin daha pozitif bir yaklaşım geliştirdiklerini belirtmişlerdir. Yapılan çalışmalar bireysel adil dünya inancı ile ruh sağlı̆̆ı arasında ve genel adil dünya inancı ile katı sosyal tutumlar arasında bir ilişkiye işaret etmektedir.

Rokeach (1971) ve Festinger'e (1957) göre, hayattaki adaletsiz sonuçların yol açtığı bilişsel uyumsuzluk ve çelişkileri gidermek için bireyler bir takım savunma stratejilerine yönelmektedir (Akt,Uğur,2007). Bazen iyi insanların kötü deneyimlerine tanık olunduğunda yani adaletsizliği gösteren işaretler ile karşılaşıldığında adil dünya inancı sarsılabilmektedir. Adil dünya inancının tehdit edilmesi durumunda bireyler bu inançlarını korumak için rasyonel veya irrasyonel (savunmacı) çeşitli stratejiler kullanabilmektedir. Rasyonel stratejiler; kurbana yardım etme, zararı tazmin etme girişimi gibi adaletsizliğin varlığını kabul ederek bunun en aza indirilmesine ya da adaletin yeniden yapılandırılmasına yöneliktir. İrrasyonel stratejiler ise adaletsizliğin varlığını yok saymayı ya da inkâr etmeyi ve adaletsiz olayın nedenini, sonucunu ve kurbanın karakterini yeniden yorumlamayı içermektedir. Dünyanın adil olduğu inancını sürdürmeyi garanti etmek onu hiç test etmemekle mümkün olabilmektedir. Dolayısıla yetişkinler çocuklardan farklı olarak ödül ve cezaların anında geleceğine (immanent justice) değil, adaletin uzun vadede sağlanabileceğine yani nihai adalete (ultimate justice) inanabilmektedir. Böylece adaletin sağlanmasında bir zaman sınırı bulunmamaktadır. Adil dünya inancı bireyin kendi dünyasını "kurbanların dünyasından" ayrıștırması yoluyla da sürdürülebilmektedir (Akgün, 2019).

Piaget'in ileri sürdüğü ve çocukların iyiliğin hemen ödüllendirileceğine ya da kötülüğün hemen cezasını bulacağına yönelik beklentilerini ifade eden "hemen gelen adalet" kavramı, adil dünya inancının kökenini oluşturmaktadır. Dalbert ve Stoeber'a (2006) göre bilişsel gelişim sürecinde çocuklar zamanla erişkinlerin güçlerinin her şeye yetmediğinin farkına varmakta ve adaletsizliğe dair edinilen deneyimlerle adalet beklentileri ergenlikte değişime uğramaktadır. Maes (1998) tarafından ileri sürülen "önünde sonunda gelecek adalet" kavramı herhangi bir adaletsizlikle karşılaşılması durumunda kişinin eninde sonunda, bu dünyada ya da ölümden 
sonra hakkı olanı alacağına inancıdır. Böylece bireylerin adil dünya inancından vazgeçmeksizin adaletin sağlanmasını beklemesi sağlanmaktadır.

\section{Adil Dünya İnancı ile İlişkili Özellikler}

Adil dünya inancına ilişkin alanyazın farklı alanları kapsamaktadır. Adil dünya inancı hakkında yürütülmüş olan ve ulaşılabilen araştırmalardan bu derlemenin kapsamıyla ilişkili olabilecek olan; aile yetişme ortamı, yaşam olayları ve baş etme biçimleri, ruh sağlığı, sorumluluk alma ve affetme gibi davranış biçimleri ile ilişkili olanlar özetlenmiştir. İş ve çalışma yaşamı ile ilgili olan araştırmalar bu alanyazın taramasında ele alınmamıştır.

Adil dünya inancının gelişimsel olarak nasıl bir seyir izlediğini ortaya koyan çalışmalarında Jose ve Brewer (1984) öyküler kullanarak adil dünya inancını çocuklarda test etmişlerdir. Araştırma bulgularına göre erken dönemlerdeki çocukların hikâyelerdeki kahramanın neyi hak ettiğinden bağımsız olarak mutlu sonla biten hikâyeleri daha fazla sevdikleri görülürken, aynı çocuklar birkaç yaş büyüdüklerinde kötü insanların başlarına kötü sonların gelmesi gerektiğini savunmuşlardır. Bir diğer değişle, yaşla birlikte adil dünya inancının geliştiği bulgusu bildirilmektedir. Çeşitli araștırmalarda adil dünya inancı cinsiyete göre ele alınmıştır. Adil dünya inancının cinsiyete bağlı bir farklılık göstermediği bildirilmektedir (Benson, 1992; O’Connur vd, 1996; Wagstaff, 1983).

Pek çok kültürde dünyanın adil bir yer olduğu vurgusunu aktarılmaktadır (Uğur ve Akgün, 2015). Ailenin yetiştirme şeklinin ve adil bir aile ortamının kişisel adil dünya inancını desteklediği, çatışmalı aile ortamının ise hem kişisel hem de genel adil dünya inancını azalttığı bildirilmektedir. Çatışma ve kişilerarası manipülasyon bulunmayan uyumlu bir aile ortamında yetişmenin güven duygusunu ve adil bir dünyaya olan inancı arttırdığı belirtilmektedir (Erdem Çevikbaș, 2018).

Adil dünya inancını içinde yetişilen kültür ve aile tutumlarının yanı sıra karşılaşılan yaşam olayları açısından da ele alan çalışmalar mevcuttur. Alanyazında travmaya maruz kalmayan bireylerle karşılaştırıldığında mağdurların dünyaya dair daha olumsuz sayıltılara sahip oldukları belirtilmektedir. Furnham ve Procter (1992) adaletsizlikle karşı karşıya kalma deneyimi arttıkça adil dünya inancının azaldığını ileri sürmüştür. Suça yönelen ergenlerle yürütülen araştırma bulgularına göre de örselenme deneyimlerini ne kadar sık yaşarlarsa o kadar az adil dünya inançları olduğunu saptanmıştır (Gökler Danışman ve Berberoğlu, 2016).

Adaletsiz deneyimlere doğrudan maruz kalmanın adil dünya inancını etkileyen en önemli faktörlerden biri olduğu vurgulanmaktadır. Toplumdaki adaletsizlikle ilişkili deneyimlere daha fazla maruz kalma özelliği doğrultusunda dezavantajlı grup üyelerinin dünyanın adil olduğu inancına daha az sahip olacakları beklenmektedir (Giray, 2009; Göregenli, 2003). Araștırmalar 
adil dünya inancı yüksek bireylerin, ait olduğu dini grubun içinde yaşadığı toplumdaki avantajlı ya da dezavantajlı durumuna bağlı olarak değişmekle birlikte, daha baskın ve dindar gruplardan çıktığını göstermektedir (Giray, 2009; Göregenli, 2003; Rubin ve Peplau,1973).

Adil dünya inancı ile ruh sağlığı, iyilik hali, stresle başa çıkma, stresli durumları ele alma arasındaki ilişkiyi ele alan araştırmaların bulguları adil dünya inancı ile pozitif duygulanım, iyimserlik, stresle etkin şekilde başa çıkma, kaliteli uyku, düşük depresyon düzeyi ve daha az yalnızlık hissi arasında ilişki olduğunu göstermektedir (Kılınç ve Torun, 2011). Adil dünya inancı ile affetme arasındaki ilişkiyi kişisel ve genel adil dünya inancı açısından ve kendini affetme açısından ele alan araştırma bulguları adil dünya inancı ile affetme kavramlarının ilişkili olduğunu göstermektedir (Demir, 2012; Strelan, 2007).

Olumsuz deneyimlerin ne gibi olumsuz sonuçları olabileceği ve bireyin ne gibi tepkiler verebileceği açısından adil dünya inancı göz ardı edilmemesi gereken bir faktördür (Dalbert, 1999, 2002). Tomaka ve Blascovich'in (1994) adil dünya inancl zaylf olanlarla karşılaştırıldığında güçlü olanlar için günlük stres yaratıcı olaylarla başa çıkma ve bu tür olayları tehdit edici olarak algılama açısından daha olumlu sonuçlar bildirmiştir. Dzuka ve Dalbert (2006), adil dünya inancı olan insanların olumsuz olaylarla karşılaştıklarında bu olayları çok fazla düşünmekten kaçınma eğilimi gösterdiklerini belirtmiştir.

Bireyler, kendi yaşantıları ve başkalarının yaşantılarını adaletsizliklere maruz kalma açısından karşılaştırmakta, bu sosyal karşılaştırmalar sonucunda ruh sağlıklarını korumak için kendi yaşantılarını başkalarının yaşantıları kadar adil algılamaya ihtiyaç duymaktadırlar. Başkalarının yaşantılarını kendi yaşantılarından daha adil algılamaları depresyon ile sonuçlanabilmektedir. Çeşitli çalışmalar (Begue ve Bastounis, 2003; Dalbert, 1999; Lipkus, Dalbert ve Siegler, 1996) bireylerin kișisel yașantılarını genel yașantılardan daha adil bulduklarını bildirmektedir. Lerner (1980) bireylerin mevcut adaletsizlikleri kendi yaşantısının dışındaki dünyada gerçekleşiyor olarak algılama ve kendi dünyasını adil değerlendirme eğiliminde olduğunu ifade etmektedir.

Bireylerin sahip oldukları adil dünya inancı doğrultusunda kendilerinin de adil biçimde davranma eğilimi gösterdikleri ileri sürülmektedir (Dalbert, 1999; Otto, Glaser ve Dalbert, 2009). Adil bir dünyada olumlu sonuçları ancak olumlu nitelikler ile hak edecekleri düşüncesiyle bireylerin dünyanın adil olduğuna inandığı ölçüde kendisini adil bir biçimde davranmaya zorunlu hissedeceği belirtilmektedir. Adil dünya inancı ile sosyal sorumluluk, kural ihlal edici davranışlar ve suç işleme niyeti arasında ilişkileri gösteren bulgular rapor edilmiştir (Correia ve Dalbert, 2008; Hafer, Begue, Choma ve Dempsey, 2005; Öcel ve Aydın, 2010). 


\section{TARTIȘMA, SONUÇ VE ÖNERİLER}

Günlük kişilerarası iletişimlerde adil dünya inancı yaygınlıkla vurgulanmakta, "ne ekersen onu biçersin", "alma mazlumun ahını çıkar aheste aheste", "etme bulma dünyası" gibi yaygınlıkla kullanılan atasözü ve deyimler aracılığıyla adil dünya inancı nesilden nesile aktarılmaktadır. Buna ek olarak dinlerin çoğu iyiliğin ödüllendirildiği ve kötülüğün cezalandırıldığı bir dünyada yaşadığımızı söylemekte ve bu dünyada olmasa bile öteki dünyada adalet vaat etmektedir (Dik, 2010; Lerner, 1980; Rubin ve Peplau, 1975). Masallar, mitolojik hikayeler, filmler aracılığıyla da dünyanın adil bir yer olduğu mesajı verilmektedir. Erken çocukluk dönemlerinde dinlenen hemen hemen tüm masallar iyi kalpli kahramanların ödüllendirilmesi ve kötülerin cezalarını çekmeleri ile sonuçlanmaktadır (Akgün, 2019).

Gerek ilk öğrenme ortamı olan ailede, gerek sosyalleşme ve eğitim yoluyla çevreden alınan mesajlarda, gerekse daha geniş bir sistem olan kitle iletişim araçları ve kültür yoluyla adil dünya inancı beklentisi oluşmakta; bir yakın ilişki biçimi olan çift ya da evlilik ilişkisi içinde birey adil dünya inancının yansımalarını yaşamaktadır. Bir diğer deyişle adil dünya inancı olan bir birey çift ya da evlilik ilişsisi içinde hak ettiğini yaşadığını ya da yaşadığını hak ettiğini düşünebilmektedir. Çift ya da evlilik ilişkisi içinde olumlu deneyimler yaşanabileceği gibi şiddet, istismar, ihmal ya da aldatma gibi olumsuz olarak değerlendirilebilecek deneyimler de yaşanabilmektedir. Bu tür olumsuz deneyimleri bireyin kendi davranışlarının bir sonucu olarak görüp görmediği ise bu deneyimleri nasıl ele alacağını belirleyecektir. Bu deneyimlerin birey tarafından ele alınırken adil dünya inancı özelliklerinin yansımalarının göz önünde bulundurulmasının çift, evlilik ve boşanma terapisi uygulamalarında katkı sağlayabileceği düşünülmektedir.

Correia ve Dalbert’a (2008) göre, adil dünya inancı bireylerin yaşamı algılamalarında, karşılaştıkları durumları yeniden yapılandırmalarında ve günlük yaşamda karşılaştıkları problemlerle baş etmelerinde bir anlam ve yorum çerçevesi sağlamaktadır (Dalbert, 2002; Tiftik, 2012). Bireyler adil dünya inancını korumak amacıyla diğerlerine ilişkin algılarını çarpıtmakta ve geçmiş olayları tekrar yorumlamaktadır (Kılınç ve Torun, 2011). Adil dünya inancı başlarına gelenleri hak ettiklerine ve hak ettiklerini elde ettiklerine inanma yatkınlıkları olduğunu ve bu yatkınlığı sürdürmek için kendi düşünme süreçlerini buna göre şekillendirdiklerini göstermektedir (Giray, 2009).

Bireylerin çift ve evlilik ilişkileri içinde yaşadıkları deneyimleri nasıl anlamlandırıp yorumladıkları sahip oldukları adil dünya inancından etkilenebilecektir. Çift ve evlilik ilişkisi içinde yaşantılarını nasıl anlamlandırıp yorumladıkları ise bu yaşantıların sonucunda nasıl hissedecekleri ve nasıl bir davranıșta bulunacakları ile ilişkili olduğundan olumsuz yașantıların sürmesine izin verip vermeme, çözüm arayışına girip girmeme, alternatif yollar geliştirip 
geliştirmeme gibi söz konusu ilişkilerin sağladığı doyum ve sürekliliğine ilişkin etkilere sahip olması beklenebilir. Böyle bir etkinin test edildiği ve derinlemesine ele alındığı nicel ve nitel araştırmalara gereksinim olduğu görülmektedir.

Dünyanın düzenli ve kararlı bir yer olduğunu düşünmeleri yoluyla bireyleri belirsizlikten koruması nedeniyle adil dünya inancının ruh sağlığının korunması üzerinde olumlu etkileri olduğu düşünülebilmektedir. Bu inancın sarsıldığı durumlarda kişi nedenler ile sonuçların uyumunu sağlayabilmek için bazı psikolojik stratejiler geliştirerek olayları tekrar gözden geçirmektedir. (Kılınç ve Torun, 2011). Adil dünya inancı kavramının gelişiminde ve devamlılığının sağlanmasında kurbanı suçlama ve değersizleştirme, adaletsizliği meşrulaştırma kavramlarından faydalanılmıştır. Bir diğer ifadeyle, başa gelen olumsuz duruma bireyin kendisinin sebep olduğu ve dolayısıyla hak ettiği, olumsuz etkilerin abartıldığı ya da gerçek olmadığı düşünülebilmektedir. Özellikle bir konuda suçlu olan kişi, örneğin şiddet uygulayan biri ya da tecavüz girişiminde bulunan biri, kendisini savunmak amacıyla söz konusu eyleme diğer tarafın davranışlarının neden olduğu belirtebilmektedir (Giray, 2009; Göregenli, 2003).

Adil dünya inancını korumak amacıyla kullanılan bilişsel stratejiler, çift ve evlilik ilişkilerinde bireylerin hem kendilerini hem de eşlerini nasıl algıladıklarını etkileyebilmektedir. Çift ve evlilik ilişkilerinde oluşan sağlıklı ve sağlıksız örüntülerin oluşması ve sürmesinde tüm tarafların pay ve sorumlulukları olduğu, ayrıca tarafların birbirlerini etkileyebildiği düşünüldüğünde çift ya da evlilik ilişkisinde bir tarafın suçlanmasının diğer tarafın pay ve sorumluluğunu görmesini engelleyebileceği beklenebilir. Adil dünya inancı bağlamında adaletsizliği meşrulaştırma, kurbanı suçlama ve değersizleştirme eğiliminin kişilerarası yakın ilişsilerde var olan döngüsel nedensellik ve etkileşim bağlamında bireylerin kendi pay, katkı ve sorumluluklarını fark etmelerini engelleyebilir.

Dalbert (1999) diğerlerinin kurbanı suçlama eğilimine ek olarak ve benzer şekilde, bir adaletsizlik durumunda adil dünya inancı güçlü olan bireylerin kendi kendilerini suçlayarak ve kendilerinin bu duruma yol açacak bir şey yaptıklarını düşünerek dünyanın adil olduğuna inanmaktan vazgeçmeden adil dünya inançlarını koruduklarını ileri sürmektedir. Comer ve Laird de (1975) adaletsizliğe uğrayan bireyin adil dünya inancını sürdürebilmek amacıyla olumsuz sonuçlara içsel nedensel yüklemeler yaptığını ileri sürmüşlerdir. (Aktaran, Öcel ve Aydın, 2010). Bir yakın kişilerarası ilişki içindeki bireyin adil dünya inancı doğrultusunda kendini suçlama eğiliminin de ilişki dinamiklerine yansımaları olacağı beklenebilir.

İnsanların adil dünya inancı yükseldikçe aile içi şiddet kurbanlarını (Kristiansen ve Giulietti, 1990), cinsel taciz kurbanlarını (Adolfsson ve Strömwall, 2017; De Judicibus ve McCabe, 2001) ve tecavüz kurbanlarını (Strömwall, Alfredsson ve Landström, 2012; Yalçın ve Öztürk, 2018) daha çok suçladıklarını gösteren çok sayıda araştırma vardır. Kurtay (2018) 
tarafından 208 kişiyle yapılan bir araştırmada evlilikte kadına yönelik fiziksel şiddeti meşrulaştırma ve adil dünya inancı arasındaki ilişkiye bakılmıştır. Genel adil dünya inancı arttıkça evlilikte kadına yönelik şiddeti meşrulaștırmanın da artış gösterdiği tespit edilmiștir.

Diğer yandan, adil dünya inancını çift ve evlilik ilişkilerinde daha farklı yönleriyle ele alan çalışmalar da mevcuttur. Hafer'e (2000) göre adil dünya inancı bireylere kendilerine adil davranılacağı ve haksız yere mağdur olmayacakları açısından güven vererek geleceklerine yatırım yapmalarını sağlamaktadır. Maes (1998) tarafından ileri sürülen önünde sonunda gelecek adalet kavramı herhangi bir haksızlık durumuyla karşılaşılması halinde kişinin önünde sonunda hakkı olanı alacağına inancıdır. Adil dünya inancının, aynı zamanda bireyleri adil biçimde davranmaya zorladığı da belirtilmektedir (Dalbert, 1999; Otto, Glaser ve Dalbert, 2009). Adil dünya inancı ile sosyal sorumluluk ve bağıșlama arasında pozitif (Strelan, 2007) ilișki bildirilmektedir. Tüm bu bulgular bir arada ele alındığında adil dünya inancı dolayısıyla bireyin çift ve evlilik ilişkisi içinde daha fazla yatırım yapması, sorumlu ve adil davranması ve karşılaştığı olumsuz durumları affetmesi beklenebilir.

Adil dünya inancı bir savunma stratejisi olarak bireylere daha güvenli ve pozitif bir bakış açısı sağlama görevine hizmet etmektedir. Adil dünya inancı yüksek bireyler daha sabit, düzgün, rasyonel ve uyumsal bir yaşam tarzına yönelmekte ve istenmedik deneyimler karşısında daha dayanıklı ve güçlü davranmaktadır. Bu bireyler, tekrarlayan istenmedik yaşantılar karşısında kolay kolay pes etmemekte ve bu yaşantıları yeni bir bilişsel şema çerçevesinde ele almaktadır (Dalbert, 2002).

Adil dünya inancının çift ve evlilik ilişkilerinde ilişkiye yatırım düzeyi ve ilişki istikrarı ya da sürekliliğiyle ilişkili olduğu düşünülebilir. Çift ve evlilik ilişkilerinin doğasında var olan olumsuz yaşantılara dayanma gücü ve ilişkiyi sürdürebilme dayanıklılı̆̆ı açısından adil dünya inancının olumlu katkı sağlayabileceğini söylemek mümkündür. Adil dünya inancının uzun vadede alınabilecek sonuçlara ilișkin umudu pekiștirdiği söylenebilir. Bununla beraber diğer yandan, çift ya da evlilik ilişkisinde sağlıklı olmayan olumsuz yaşantılara da tolerans ve dayanıklılık gösterilmesini sağlayabilecektir.

Begue ve Muller (2006), adil dünya inancının kişilerarası güvenle ilişkili bir adaletsizliğin algılandığı istenmedik yaşantılarda bir tampon gibi işlev gösterdiğini ileri sürmüştür. Adil dünya inancının yüksek olması kişilerarası ilişkileri olumlu yönde etkilemektedir. Bir diğer ifadeyle bir ilişki ya da evlilik içindeki partnerler adil dünya inançlarının yüksekliği ölçüsünde diğer tarafın olumsuz davranışlarını tolere edebilmektedir (Lipkus \& Bissonnette,1996).

$\mathrm{Bu}$ açılardan ele alındığında adil dünya inancı bir yandan bireyin olumsuz deneyimleri hak ettiğine inanmasına yani deneyimin mağduru olarak kendisini suçlamasına yol açabilmekte, 
fakat diğer yandan birey olumsuz deneyimleri gelecek adalet beklentisi ile de ele alabilmektedir. Çift ya da evlilik ilişkisi içinde yaşanabilecek şiddet, istismar, ihmal ya da aldatma döngüleri ve affetme, ilişkide kalma ya da ilişkiden ayrılma süreçleri açısından adil dünya inancının bu iki yönünün çift, evlilik, aile ya da boşanma süreci danışmanlığında ele alınmasının katkı sağlayabileceği düşünülmektedir. Adil dünya inancının yakın kişiler arası ilişkiler ve aile çalışmalarında ele alınmasına yönelik bu derleme çalışmasından elde edilen sonuçların, bu alandaki çalışmaların eksikliğine işaret etmesi ve daha ileri çalışmalara olan gereksinime dikkat çekmesi beklenmektedir. Yakın kişilerarası ilişkiler ve aile çalışmalarında şiddet, ihmal, istismar, aldatma, terk edilme gibi durumlarda bireylerin bu duruma maruz kalan partneri ve bu duruma yol açan partneri adil dünya inancı açısından nasıl ele aldığı, kendisi böyle durumlara maruz kaldığında ya da yol açtığında adil dünya inancına göre nasıl bir tutum sergilediği, ilişki ya da evlilik beklentilerinin ve bir ilişkinin nasıl olması gerektiğine dair inançlarının adil dünya inancına göre nasıl șekillendiği, ilişki ya da evlilik içinde kendi davranışlarını, yatırımlarını ve sorumluluğunu adil dünya inancına göre nasıl düzenlediği, affetme, ilişki ya da evliliği sürdürme veya sonlandırma döngü ve kararlarında adil dünya inancının nasıl bir etkisinin olduğu, evlilik ilişkisinin sonlanması anlamına gelen boşanma durumunu adil dünya inancı açısından nasıl anlamlandırdığı ve bu ele alış biçiminin boşanma süreci ve sonrası uyumunu nasıl etkilediği gibi konularda gerek nitel, gerekse nicel ya da her iki türde daha ileri araștırmaların planlanıp yürütülmesi önerilmektedir. Bu tür araştırmaların bulgularından çift, evlilik, aile ve boşanma terapisi alanındaki araştırmacı ve uygulayıcılar fayda sağlayabilecek ve böylelikle çift, evlilik, aile ve boşanma terapisi uygulamalarının daha etkili olarak yürütülmesine katkı sağlayabilecektir. 


\section{KAYNAKÇA}

Adolfsson, K. \& Strömwall, L. A. (2017). Situational variables or beliefs? A multifaceted approach to understanding blame attributions. Psychology, Crime \& Law, 23(6), 527-552. https://doi.org/10.1080/1068316X.2017.1290236

Akgün, S. (2019). Adil dünya inancı ve toplumsal sonuçları. OPUS- Uluslararası Toplum Araştırmaları Dergisi, 14 (20), 2227- 2247. https://doi.org/10.26466/opus.610173

Begue, L. \& Bastounis, M. (2003). Two spheres of belief in justice: Extensive support for the bidimensional model of belief in a just world. Journal of Personality, 73, 435-463. https://doi.org/10.1111/1467-6494.7103007

Begue, L. \& Muller, D. (2006). Belief in a just world as moderator of hostile attributional bias. $\begin{array}{lllll}\text { British Journal of Social Psychology, 45, } & 117-126\end{array}$ https://doi.org/10.1348/014466605X37314

Benson, D. (1992). Why do people believe in a just world: Testing explanations. Sociological Spectrum, 12, 73-104 https://doi.org/10.1080/02732173.1992.9981988

Çakır, K. \& Şen, E. (2012). Psikolojik doğum sırasına göre adil dünya inancı. Sosyal Bilimler Enstitüsü Dergisi, 32, 57-69.

Calhoun, L., \& Cann, A. (1994). Differences in assupptions about a just world: Ethnicity and point of view. Journal of Social Psychology, 134(6), 765. https://doi.org/10.1080/00224545.1994.9923011

Correia, I., Kamble, S. V. \& Dalbert, C. (2009). Belief in a just world and well-being of bullies, victims and defenders: A study with Portuguese and Indian students. Anxiety, Stress, \& Coping: An International Journal, 22(5), 497-508. https://doi.org/10.1080/10615800902729242

Correria, I., \& Dalbert, C. (2008). School bullying: Belief in a personal just world of bullies, victims, and defenders. European Psychologist, 13, 248-254. https://doi.org/10.1027/1016-9040.13.4.248

Coşgun, E. (2010). Suça yönelen ergenlerde çocukluk döneminde örseleyici yaşantılara maruz kalma düzeyi ile adil dünya inancı arasındaki ilişkinin incelenmesi. [Yayımlanmamış Yüksek Lisans Tezi]. Marmara Üniversitesi.

Dalbert D. E. \& Stoeber J. (2006). The belief in a just world and domain-spesific beliefs about justice at school and in the family: A longitudinal study with adolescents. International Journal of Behavioral Development, 30, 200-207. https://doi.org/10.1177/0165025406063638

Dalbert, C. (1999). The world is more just for me than generally: About the personal belief in a just world scale's validity. Social Justice Research, 12, 79-98. https://doi.org/10.1023/A:1022091609047

Dalbert, C. (2002). Beliefs in a just world as a buffer against anger. Social Justice Research, 15, 123-145. https://doi.org/10.1023/A:1019919822628

De Judicibus, M., \& McCabe, M. P. (2001). Blaming the target of sexual harassment: Impact of gender role, sexist attitudes, and work role. Sex Roles, 44, 401-417. https://doi.org/10.1023/A:1011926027920

Demir, A. (2012). Akran zorbalığına karışan ve karışmayan ilköğretim öğrencilerinin utanç ve suçluluk duygularının ve adil dünya inançlarının incelenmesi. [Yayımlanmamış Yüksek Lisans Tezi]. Maltepe Üniversitesi.

Dik, T. (2010). Atasözlerinde adil dünya inancı. Milli Folklor, 22 (88), 28-32. 
Dzuka, J., \& Dalbert, C. (2006). The belief in a just world's impact on subjective well-being in old age. Aging and Mental Health, 10, 439-444. https://doi.org/10.1080/13607860600637778

Erdem Çevikbaş, P. (2018). Ortaokul ve lise öğrencilerinin adil dünya inançlarının denetim odağı ve anne baba tutumu açısından gelişimsel olarak incelenmesi. [Yayımlanmamış Doktora Tezi]. Hacettepe Üniversitesi.

Furnham, A., \& Procter, E. (1992). Sphere-specific just world beliefs and attitudes to AIDS. Human Relations, 45, 265-280. https://doi.org/10.1177/001872679204500303

Giray, F. S. (2009). Suç işlemiş ve işlememiş ergenlerin adil dünya inancı ve bağışlayıcılık tutumları arasındaki ilişkinin incelenmesi. [Yayımlanmamış Yüksek Lisans Tezi]. Maltepe Üniversitesi.

Gökler Danışman, B., \& Berberoğlu, I. (2016). Suça yönelen ergenlerde, çocukluk döneminde örseleyici yaşantılara maruz kalma düzeyi ile adil dünya inancı arasındaki ilişkinin incelenmesi. Anadolu Psikiyatri Dergisi, 17(2). 111-119. https://doi.org/10.5455/apd.177638

Göregenli, M. (2003). Şiddet, kötü muamele ve işkenceye ilişkin değerlendirmeler, tutumlar ve deneyimler. İşkencenin Önlenmesinde Hukukçuların Rolü Projesi Raporu. İzmir.

Hafer, C. (2000). Investment in long-term goals and commitment to just means drive the need to believe in a just world. Personality and Social Psychology Bulletin, 26, 1059-1073. https://doi.org/10.1177/01461672002611004

Hafer, C., Begue, L., Choma, B., \& Dempsey, J. (2005). Belifs in a just world and commitment to long-term deserved outcomes. Social Justice Research, 18, 429-443. https://doi.org/10.1007/s11211-005-8569-3

Harper, D. J. \& Manesse, P. R. (1992). The just world and the third world: British explanations for poverty abroad. Journal of Social Psychology, 132(6), 783-785. https://doi.org/10.1080/00224545.1992.9712107

Harper, D. J., Wagstaff, G. F., Newton, J. T., \& Harrison, L. R. (1990). Lay causal perceptions of third world poverty and the just world theory. Social Behavior and Personality, 18, 235238. https://doi.org/10.2224/sbp.1990.18.2.235

Heider, F. (1958), The psychology of interpersonal relations. Lawrence Erlbaum Associates.

Janoff-Bulman, R. (1989). Assumptive worlds and the stress of traumatic events: Applications of the schema construct. Social Cognition, 7, 113-136. https://doi.org/10.1521/soco.1989.7.2.113

Jose, P. E., \& Brewer, W. F. (1984). Development of story liking: character identification, suspense, and outcome resolution. Developmental Psychology, 20(5), 911-924. https://doi.org/10.1037/0012-1649.20.5.911

Kılınç, S. \& Torun, F. (2011). Adil dünya inancı. Psikiyatride Güncel Yaklaşımlar, 3 (1), 1-14.

Kleinke, C. L., \& Meyer, C. (1990). Evaluation of rape victim by men and women with high and low belief in a just world. Psychology of Women Quarterly, 14, 343-353. https://doi.org/10.1111/j.1471-6402.1990.tb00024.x

Kristiansen, C., \& Giulietti, R. (1990). Perceptions of wife abuse: Effects of gender, attitudes toward women, and just-world beliefs among college students. Psychology of Women Quarterly, 14, 177-189. https://doi.org/10.1111/j.1471-6402.1990.tb00013.x

Kurtay, C. (2018). Evlilikte kadına yönelik fiziksel şiddeti meşru görme ile cinsiyetçi tutumlar ve adil dünya inancı arasındaki ilişsinin incelenmesi. [Yayımlanmamış Yüksek Lisans Tezi]. Arel Üniversitesi. 
Lerner, M. \& Simmons, C. (1966). Observer's reaction to the "innocent victim": Compassion or rejection? Journal of Personality and Social Psychology, 4, 203-210. https://doi.org/10.1037/h0023562

Lerner, M. (1965). Evaluation of performance as a function of performer's reward and attractiveness. Journal of Personality and Social Psychology, 1, 355-360. https://doi.org/10.1037/h0021806

Lerner, M. (1977). The justice motive: Some hypotheses as to its originsand forms. Journal of Personality, 45, 1-52. https://doi.org/10.1111/j.1467-6494.1977.tb00591.x

Lerner, M. (1980). The belief in a just world: A fundamental delusion. New York Plenum Press

Lipkus, I. M. \& Siegler, I. C. (1993). The belief in a just world and perceptions and discrimination. Journal of Psychology, 127, 465-474. https://doi.org/10.1080/00223980.1993.9915583

Lipkus, I., \& Bissonnette, V. (1996), Relationships among the belief in a just world, willingness to accommodate and marital well-being. Personality and Social Psychology Bulletin, 22, 1943-1956. https://doi.org/10.1177/01461672962210008

Lipkus, I., Dalbert, C., \& Siegler, I. (1996). The importance of distinguishing the belief in a just world for self versus for others: Implications for psychological well being. Personality and Social Psychology Bulletin, 22, 666-677. https://doi.org/10.1177/0146167296227002

Maes J. (1998). Immanent justice and ultimate justice: two ways of believing in justice. In L. Montada \& M. J. Lerner (Eds), Responses to Victimizations and Belief in a Just World (pp. 940). Plenium Press.

Montada, L. (1998). Belief in a just world: A hybrid of a justice motive and self-interest? In L. Montada \& M.J. Lerner (Eds), Reponses to Victimization and Belief in a Just World (pp. 217-241). Plenum Press.

O’Connur, W., Morrison, T., Mcleod, L. \& Anderson, D. (1996). A

meta-analytic review of the relationship between gender and belief in a just world. Journal of Social Behavior and Personality, 1, 141-148.

Öcel, H., \& Aydın, O. (2010). Adil dünya inancı ve cinsiyetin üretim karşıtı iş davranışları üzerinde etkisi. Türk Psikoloji Dergisi, 25 (66), 73-83.

Otto, K., \& Dalbert, C. (2005). Belief in a just world and its function for young prisoners. Journal of Research in Personality, 39, 559-573. https://doi.org/10.1016/j.jrp.2005.01.004

Otto, K., Glaser, D., \& Dalbert, C. (2009). Mental health, occupational trust and quality of working life: Does belief in a just world matter? Journal of Applied Social Psychology, 39, 12881315. https://doi.org/10.1111/j.1559-1816.2009.00482.x

Rubin, Z., \& Peplau, A. (1975). Who believes in a just world? Journal of Social Issues, 31, 65-89. https://doi.org/10.1111/j.1540-4560.1975.tb00997.x

Rubin, Z., \& Peplau, A. (1973). Belief in a just world and reactions to another's lot: A study of participants in the national draft lottery. Journal of Social Issues, 29, 73-93. https://doi.org/10.1111/j.1540-4560.1973.tb00104.x

Strelan, P. (2007), The prosocial, adaptive qualities of just world the relationship between justice and forgiveness.

beliefs: implications for Differences, 43, 881-890. https://doi.org/10.1016/j.paid.2007.02.015

Strömwall, L. A., Alfredsson, H., \& Landström, S. (2012). Blame attributions and rape: effects of beliefin a just world and relationship level. Legal and Criminological Psychology, 18, 254261. https://doi.org/10.1111/j.2044-8333.2012.02044.x 
Tiftik, N. (2012). Adam öldürme eylemi nedeniyle hüküm giymişs olan kadınlarda, çocukluk örselenme yaşantılarına maruz kalma düzeyi, adil dünya inancı ve öfke ifade tarzları arasındaki ilişkinin incelenmesi. [Yayımlanmamış Yüksek Lisans Tezi]. Maltepe Üniversitesi.

Tomaka, J., \& Blascovich, J. (1994). Effects of justice beliefs on cognitive appraisal of and subjective, physiological, and behavioral responses to potential stress. Journal of Personality and Social Psychology, 67, 732-740. https://doi.org/10.1037/00223514.67.4.732

Uğur, D. (2007). Dünyayı adil algılama ve geleceğe dair umut/umutsuzluk: depresyon tanısı alan ve almayan kişilerde adil dünya inancı. [Yayımlanmamış Yüksek Lisans Tezi]. Mersin Üniversitesi.

Uğur, D., \& Akgün, S. (2015). Bireysel ve genel dünya inancının depresyon ile ilişkisi. Ankara Üniversitesi Sosyal Bilimler Dergisi, 6 (1). 103-116.

Wagstaff, G. (1983). Correlates of just world in Britain. The Journal of Social

Psychology, 121, 145-146. https://doi.org/10.1080/00224545.1983.9924476

Yalçın, M. A., \& Öztürk, E. (2018). Cinsel saldırı suçu mağduru kadınlara karşı toplumsal tutumlar ile adil dünya inancı ve çelişik duygulu cinsiyetçiliğin ilişkisi. Türkiye Klinikleri Journal of Forensic Medicine and Forensic Sciences, 15(2), 43-51. 


\section{EXTENDED ABSTRACT}

\section{Introduction}

Belief in a just world has been an emerging concept in the fields such as mental health, forensic psychology, industrial-organizational psychology, social psychology and religion psychology in the last decades. The literature on the quality, process, impact and consequences of the concept of belief in a just world has been developing at both individual, relational and social levels. According to Lerner's $(1965 ; 1977 ; 1980)$ just world belief theory, individuals believe that the world is a fair place, that everyone lives what they deserve and deserves what they live. The recognition of the tendency of individuals to rationalize the injustices in the events they encounter has been effective in suggesting the theory of belief in a just world. Thus, early studies of belief in a just world commonly focus on the tendency to justify injustice and victim blaming (Kılınç ve Torun, 2011).

The fields of couple, marriage, family and divorce counseling include remedial and developmental practices related to the preparation, maintenance and termination stages of marriage, which is a special type of close interpersonal relationship. A limited number of studies have been found in which the belief in a just world is discussed within the scope of couple, marriage and family relations studies, and it has been seen that there is a gap in this field. It is thought that the belief in a just world can be an important concept that can be considered within the scope of couple, marriage, family and divorce process counseling fields where close interpersonal relationships are discussed. It is thought that considering the concept of belief in a just world in the fields of close interpersonal relations may contribute to a better understanding of the effects and results of this concept on individuals and the relationship dynamics between them, and in the practices of couple, marriage, family and divorce process counseling. Thus, it was thought that recognizing the reflections of the belief in a just world on the practices in the fields of couple, marriage, family and divorce counseling could serve to increase effectiveness of these interventions.

\section{Discussion \& Conclusion}

The belief in a just world is widely emphasized in daily interpersonal communications, and cultural elements such as religions, fairy tales, mythological stories, movies, commonly used proverbs and idioms. Throgh these mesaages, the expectation of belief in a just world is emerging and in the couple or marriage relationship, which is a form of close relationship, the individual experiences the reflections of this belief in a just world. In other words, an individual with a belief in a just world may think that s/he deserves what s/he lives and s/he lives what $\mathrm{s} /$ he deserves in a couple or marriage relationship. While there may be positive experiences in 
the couple or marital relationship, there may also be negative experiences such as violence, abuse, neglect or cheating. How the individual percieves such negative experiences will determine how s/he will handle these experiences. According to Correia and Dalbert (2008), belief in a just world provides a framework of meaning and interpretation for individuals to perceive life, reconstruct the situations they encounter, and cope with the problems they encounter in daily life. It can be expected that this framework can effect how the partners will feel and how they will behave regarding the satisfaction and the stability of their close relationship. In the context of belief in a just world, the tendency to justify injustice, victim blaming and victim derogaiton may prevent individuals from realizing their share, contribution and responsibilities in the context of circular causality and interaction in interpersonal close relationships. 